\title{
Pilot Study of Lung Function Improvement in Peak Expiratory Flow (PEF) Value Using Fish Oil Containing Omega-3 Therapy in Asthma
}

\author{
Amelia Lorensia, ${ }^{1}$ Rivan Virlando Suryadinata, ${ }^{2}$ Richa Ratnasari ${ }^{3}$ \\ ${ }^{1}$ Department of Clinical-Community Pharmacy, Faculty of Pharmacy, Universitas Surabaya, Surabaya, Indonesia, \\ ${ }^{2}$ Department of Public Health, Faculty of Medicine, Universitas Surabaya, Surabaya, Indonesia, \\ ${ }_{3}^{3}$ Pharmacy Undergraduate Study Program, Faculty of Pharmacy, Universitas Surabaya, Surabaya, Indonesia
}

\begin{abstract}
Fish oil contains omega-3 as an anti-inflammatory effect that can inhibit the production of arachidonic acid 5 -lipoxygenase (ALOX5), an enzyme that aggravates the inflammation of the lungs that cause asthma. This study aims to determine the effect of omega- 3 from fish oil on improving lung function with peak expiratory flow (PEF) value in patients with outpatient asthma in Surabaya. The research design used in this research is pre-post test design and lung function examination by using a peak flow meter. Then follow up every week for four weeks during the use of fish oil, and the results of his research were analyzed by t test. The study was conducted from April 2017 until January 2018 in Surabaya. The sample of the study was 27 adult asthma patients. The results showed that most of the study subjects had an increase in PEF value every week. Besides, there was a significant increase of PEF values gradually at $\mathrm{T}_{0}$ (before intervention) to $\mathrm{T}_{4}$ (intervention for four weeks), indicating an improved effect after the use of fish oil in a four-week study sample. In conclusion, fish oil containing omega-3 is effective in improving lung function in outpatient asthma patients.
\end{abstract}

Key words: Asthma, fish oil, omega-3, peak expiratory flow

\section{Pilot Studi Perbaikan Fungsi Paru menurut Nilai Peak Expiratory Flow (PEF) Menggunakan Terapi Minyak Ikan Mengandung Omega-3 pada Asma}

\begin{abstract}
Abstrak
Minyak ikan mengandung omega-3 sebagai efek antiinflamasi yang dapat menghambat produksi asam arakidonat 5-lipoksigenase (ALOX5) merupakan enzim yang memperburuk peradangan paru yang menyebabkan asma. Penelitian ini bertujuan mengetahui pengaruh omega-3 dari minyak ikan terhadap perbaikan fungsi paru dengan nilai peak expiratory flow (PEF) pada pasien asma dewasa rawat jalan di Surabaya. Desain penelitian yang digunakan dalam penelitian ini adalah pre-post test dan pemeriksaan fungsi paru menggunakan peak flow meter. Kemudian dilakukan follow up setiap minggu selama empat minggu selama penggunaan minyak ikan dan hasilnya dianalisis dengan uji t. Penelitian dilakukan pada April 2017 hingga Januari 2018 di Surabaya. Sampel penelitian sebanyak 27 pasien asma dewasa. Hasil penelitian menunjukkan bahwa sebagian besar subjek penelitian mengalami peningkatan nilai PEF setiap minggunya. Selain itu, terdapat peningkatan signifikan nilai PEF secara bertahap pada $\mathrm{T}_{0}$ (sebelum intervensi) sampai $\mathrm{T}_{4}$ (intervensi selama empat minggu) yang menunjukkan efek membaik setelah penggunaan minyak ikan pada sampel penelitian selama empat minggu. Simpulan, minyak ikan yang mengandung omega-3 terbukti efektif dalam perbaikan fungsi paru pada pasien asma rawat jalan..
\end{abstract}

Kata kunci: Asma, minyak ikan, omega-3, peak expiratory flow 


\section{Introduction}

Asthma is defined as chronic inflammation of the airways, with respiratory symptoms such as wheezing, shortness of breath, chest tightness, and coughing that vary over time and intensity, together with variable limitations of expiratory airflow. ${ }^{1}$ The Ministry of Health estimates that asthma is among the top 10 causes of illness and death in hospitals. ${ }^{2}$ According to Global Burden data, asthma has increased and is now ranked $28^{\text {th }}$ as a disease that affects one's adjusted-life year. ${ }^{3}$ Adverse effects of asthma include decreased quality of life, decreased productivity, absence from school, increased health costs, increased risk of hospitalization, and even death. ${ }^{4}$

The treatment has now shifted from synthetic drugs to nutritional treatments. Therapy with synthetic drugs still often causes drug-related problems, both in drug selection, difficulties in using tools, the emergence of side effects, to the cost burden that is greater than it should be..$^{-12}$ Lifestyle consumption of nutrients plays an essential role in developing several diseases, including inflammatory diseases as a cause of asthma. 5 Consumption of fish can prevent asthma in adult patients. Research shows that fish consumption at least once a month, can reduce the risk of asthma. ${ }^{13}$ Populations with high intakes of fish also have low levels of asthma. This theory states that fish oil content can reduce inflammation that causes swelling in the lung channels leading to asthma attacks. ${ }^{14}$ Fish oil is a very effective nutrient containing essential omega-3 fatty acids and can be absorbed easily. Fish oil contains docosahexaenoic acid (DHA) and eicosapentaenoic acid (EPA). ${ }^{13}$ Omega-3 contained in fish oil is considered a potential therapy for asthma and other inflammatory diseases. Fish oil inhibits the production of arachidonic acid 5-lipoxygenase (ALOX5), an enzyme that exacerbates inflammation of the lungs that causes asthma. ${ }^{15}$

Indonesia, a maritime country, has excellent fish production potential, which can process fish oil, such as salmon, cod, etc. Meanwhile, several studies related to fish oil have also been carried out, which contain omega-3 as conducted by Aprizayanti, ${ }^{16}$ and Santoso et al. ${ }^{17}$ However, there are no studies related to the effect of omega- 3 in fish oil on asthma improvement. Control of asthma symptoms is also related to the limitations of the expiratory airflow variable. The function of lung expiration varies from time to time and is more significant than in healthy populations.1 Many methods for assessing lung physiology have been widely accepted as a standard. It is spirometry and peak expiratory flow (PEF) examinations. PEF self-monitoring can be useful in asthma management, especially in those with low perceptions of their airways. ${ }^{12}$ Peak expiratory flow has a unique role in the initial investigation of asthma work, where pulmonary testing functions are often needed. ${ }^{18}$

Hopefully, this research can improve knowledge related to the nutrition of asthma. Also, pharmacists' role supports the management of asthma and provides information, counseling, and education. So, they better understand the treatment regimen given so patients can play an active role in their treatment, improving their compliance with the drug. In the integrated team, the pharmacist's role is to provide recommendations in the selection of appropriate drugs based on the patient's condition obtained from the results of the interview and the results of the doctor's diagnosis. ${ }^{4}$ This study aims to determine the effect of omega- 3 from fish oil on lung function improvement with $\mathrm{PEF}$ values in outpatient adult asthma patients in Surabaya.

\section{Methods}

The research design was the pre-post test design, examining lung function using a peak flow meter. The study was conducted from April 2017 until January 2018, with ethical tests that have been conducted and get number 004/KE/I/2017 at the Institutional Ethical Committee of the University of Surabaya. The composition in fish oil given was 1000 mg omega-3, 180 mg EPA, 120 mg DHA. Fish oil was given to patients and then followed up every week for four weeks with a once-daily dose that was proven to consume fish oil at least once a month can reduce the risk of asthma, with a dose of 1 gram to 5.4 grams per day. ${ }^{19}$ So, in this study, selected fish oil with a dose of 1.0 gram.

This study's variable was the value of PEF in outpatient asthma patients. The peak flow meter was a measure of PEF. Peak expiratory flow (PEF) can indicate the degree of limited airflow. For each type of peak flow meter, the PEF value obtained was also different. Respondents were asked to measure lung function's value using a peak flow meter 3 times and see the best value. Measurement using a peak flow meter was performed by patients with the researchers' assistance six times in 6 weeks after consuming 


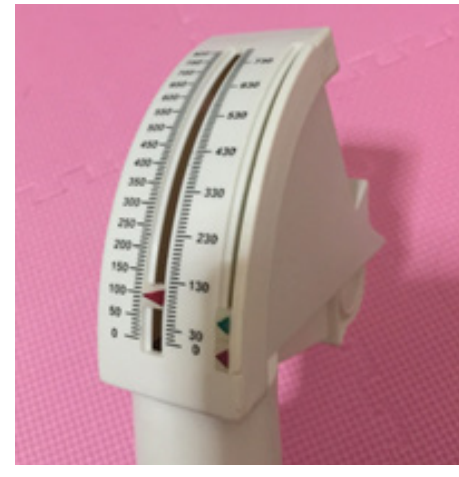

Figure Peak Flow Meter

fish oil for one week.

The study population was outpatient asthma patients. The research sample was with the following inclusion criteria were adults age 1845 years, and patients were willing to participate in the study voluntarily after receiving informed consent. Exclusion criteria: (1) having a disease that can affect the data collection process requires a differential diagnosis. These diseases include bronchitis, chronic obstructive pulmonary disease (COPD), sinusitis, vocal cord dysfunction, bronchiectasis, heart disease, alpha1 deficiencyantitrypsin, pulmonary embolism, and kidney disorders. It also excludes patients, which is (2) smoking or stopping smoking <2 years, and (3) patients who used routine asthma medication (controller). The research subjects were obtained by purposive sampling method.

A paired $t$ test was used to determine the presence or absence of an average difference between 2 groups of related samples. One sample underwent two different treatments. Test the
Table 1 Distribution of Frequency of Characteristics of Respondents

\begin{tabular}{lc}
\hline Characteristics & n=27 \\
\hline Gender & 7 \\
Male & 20 \\
Female & \\
Age (year) & 25 \\
Late teens (17-25) & 1 \\
Early adults (26-35) & 1 \\
Late adults (36-45) & \\
Asthma medication used & 8 \\
Short-acting oral beta-2 agonist & 10 \\
Short-acting inhalation beta-2 agonist & 1 \\
Not currently using any medicine & 2 \\
Agonist $\beta-2$ long work inhalation & 4 \\
Oral methylxanthine & 1 \\
Oxygen & 8 \\
Other & 3 \\
Not currently using any medicine & \\
\hline
\end{tabular}

difference between observations before and after therapy, using paired $t$ test. This pooled $t$ test was used to determine whether there was an average difference between the two unrelated sample groups. Test the difference between observing PEF values at week $O$ and week 4 in patients receiving fish oil therapy.

\section{Results}

In Table 1, explaining the number of samples (subjects) of male research was less than female respondents, with most ages ranging from 17-25 years. Most subjects (10 of 27) used a shortacting beta-2 agonist by the inhalation route

Table 2 Changes in Peak Expiratory Flow Value After Giving Fish Oil Therapy

\begin{tabular}{lccc}
\hline \multirow{2}{*}{ Groups being Compared } & \multicolumn{2}{c}{ Frequency of Subjects Changing PEF Value (L/sec) } \\
\cline { 2 - 4 } & Increased & Fixed & Decreased \\
\hline To and T1 & 20 & 2 & 5 \\
To and T2 & 21 & 1 & 5 \\
To and T3 & 20 & 1 & 6 \\
To and T4 & 24 & 1 & 2 \\
T1 and T2 & 20 & 0 & 7 \\
T2 and T3 & 16 & 2 & 9 \\
T3 and T4 & 21 & 0 & 6 \\
\hline
\end{tabular}

Note: PEF=peak expiratory flow; To=week 0 , the study sample has not received the intervention; $\mathrm{T} 1=$ in the first week, the test group's research sample had received the intervention (fish oil) for one week; T2=in the $2^{\text {nd }}$ week, the test group sample had received the intervention (fish oil) for two weeks; $T_{3}=$ in the $3^{\text {rd }}$ week, the test group's research sample had received the intervention (fish oil) for three weeks; $\mathrm{T} 4=$ in the $4^{\text {th }}$ week, the test group's study sample had received the intervention (fish oil) for four weeks 
Table 3 Average Peak Expiratory Flow Values

\begin{tabular}{|c|c|c|c|c|c|c|c|c|c|}
\hline \multicolumn{4}{|c|}{$\begin{array}{c}\text { Average }(\overline{\mathbf{x}}) \\
\text { Changes in PEF Values from Before } \\
\text { Therapy compared to when Given } \\
\text { Fish Oil Therapy }\end{array}$} & \multirow{2}{*}{$\begin{array}{c}\begin{array}{c}\text { Time } \\
\text { of Data } \\
\text { Collection } \\
\text { for PEF }\end{array} \\
\text { To }\end{array}$} & \multirow{2}{*}{$\begin{array}{c}\text { Average } \\
\text { PEF } \\
\text { Value (L/ } \\
\text { sec) } \\
217.96\end{array}$} & \multicolumn{4}{|c|}{$\begin{array}{c}\text { Average }(\overline{\mathbf{x}}) \\
\text { Changes in PEF values from Before } \\
\text { Therapy compared to when Given } \\
\text { Fish Oil Therapy }\end{array}$} \\
\hline \multirow{5}{*}{$\begin{array}{l}\overline{\mathrm{X}}_{\mathrm{To}-\mathrm{T} 4}= \\
107.04\end{array}$} & \multirow{5}{*}{$\begin{array}{c}\overline{\mathrm{X}}_{\mathrm{To}-\mathrm{T} 3}= \\
80.93\end{array}$} & \multirow{5}{*}{$\begin{array}{c}\overline{\mathrm{X}}_{\mathrm{To}-\mathrm{T} 2}= \\
77 \cdot 59\end{array}$} & $\overline{\mathrm{X}}_{\mathrm{To}-\mathrm{T} 1}=$ & & & $\overline{\mathrm{X}}_{\mathrm{T} 1-\mathrm{To}}=$ & & & \\
\hline & & & 55.19 & $\mathrm{~T} 1$ & 273.15 & 55.19 & $\overline{\mathrm{X}}_{\mathrm{T} 2-\mathrm{T} 1}=$ & & \\
\hline & & & & $\mathrm{T} 2$ & 295.56 & & 22.41 & \multirow{3}{*}{$\begin{array}{c}\overline{\mathrm{X}}_{\mathrm{T} 3-\mathrm{T} 2}= \\
3 \cdot 33\end{array}$} & \\
\hline & & & & $\mathrm{T}_{3}$ & 298.89 & & & & $\overline{\mathrm{x}}_{\mathrm{T}_{4}-\mathrm{T}_{3}}=$ \\
\hline & & & & $\mathrm{T}_{4}$ & 325.00 & & & & 26.11 \\
\hline \multicolumn{4}{|c|}{$\begin{array}{l}\text { Conclusion: all experienced an increase } \\
\text { in PEF values after } 4 \text { weeks on average } \\
\text { by } 107.04\end{array}$} & & & \multicolumn{4}{|c|}{$\begin{array}{l}\text { Conclusion: all have increased but the } \\
\text { numbers are not significant every week }\end{array}$} \\
\hline
\end{tabular}

(salbutamol MDI) as asthma therapy was used only when asthma symptoms appeared.

Most research subjects experienced an increase every week after the use of fish oil (Table 2). In Table 3, it was known that there was an increase in PEF values at To to $\mathrm{T}_{4}$. It showed an improved effect after the use of fish oil in the study sample for four weeks. However, the increase did not occur similarly every week. T2$\mathrm{T} 1 \mathrm{had}$ an average increase of $22.41 \mathrm{~L} / \mathrm{sec}, \mathrm{T}_{3}-\mathrm{T}_{2}$ had an average increase of $3.33 \mathrm{~L} / \mathrm{sec}$, and $\mathrm{T} 4-\mathrm{T} 3$ had an average increase of $26.11 \mathrm{~L} / \mathrm{sec}$.

The normality test used Shapiro-Wilk because of the number of samples $<50$ subjects.

Table 4 Normality Test for Peak Expiratory Flow Values

\begin{tabular}{lc}
\hline Groups & p Value $^{*}$ \\
\hline To & 0.002 \\
T1 & 0.131 \\
T2 & 0.109 \\
T3 & 0.209 \\
T4 & 0.089 \\
\hline
\end{tabular}

Note: "Shapiro-Wilk test; To=week o, the study sample has not received the intervention; $\mathrm{T} 1=\mathrm{in}$ the first week, the test group's research sample had received the intervention (fish oil) for one week; T2=in the $2^{\text {nd }}$ week, the test group sample had received the intervention (fish oil) for two weeks; $T_{3}=$ in the $3^{\text {rd }}$ week, the test group's research sample had received the intervention (fish oil) for three weeks; $\mathrm{T} 4=$ in the $4^{\text {th }}$ week, the test group's study sample had received the intervention (fish oil) for four weeks; $p>0.05$ means normal distribution and $\mathrm{p}<0.05$ means that the distribution is not normal
Normality tests regarding the research samples' PEF values at To, T1, T2, T3, and $\mathrm{T}_{4}$ found that $\mathrm{T} 1, \mathrm{~T} 2, \mathrm{~T}_{3}$, and $\mathrm{T}_{4}$ groups were normally distributed $(\mathrm{p}>0.05)$. However, the to group was not normally distributed (non-parametric) (p<0.05, Table 4).

The normality test in Tabel 4 used a paired $t$ test if it is normally distributed while a normally distributed Wilcoxon signed-rank test is used. Table 5 showed that there was a significant

\section{Table 5 Statistical Tests of Peak Expiratory Flow Intervention Groups by Ratio Scale}

\begin{tabular}{lc}
\hline Groups & p Value \\
\hline To and T1 & $0.014^{*}$ \\
To and T2 & $0.003^{*}$ \\
To and T3 & $0.009^{*}$ \\
To and T4 & $0.000^{*}$ \\
T1 and T2 & $0.000^{* *}$ \\
T2 and T3 & $0.013^{* *}$ \\
T3 and T4 & $0.017^{* *}$ \\
\hline
\end{tabular}

Note: "Wilcoxon signed-rank test; "** paired t test; To=week $\mathrm{o}$, the study sample has not received the intervention; $\mathrm{T} 1=\mathrm{in}$ the first week, the test group's research sample had received the intervention (fish oil) for one week; T2=in the $2^{\text {nd }}$ week, the test group sample had received the intervention (fish oil) for two weeks; $T_{3}=$ in the $3^{\text {rd }}$ week, the test group's research sample had received the intervention (fish oil) for three weeks; T4=in the $4^{\text {th }}$ week, the test group's study sample had received the intervention (fish oil) for four weeks; $p>0.05$ : Ho is rejected, meaning there is no significant difference; $p<0.05$ : Ho accepted means that there are significant differences 
increase every week in the PEF values of study subjects. The most significant increase occurred in the first week (T1) of fish oil administration compared to before therapy (To, Table 3).

\section{Discussion}

The PEF value estimated the peak expiratory rate. It is the fastest measure of airspeed exhaled by the lungs after inhaling a long breath expressed in units of liters per second (L/sec). Peak flow meters were used to assess the PEF. The peak flow in patients may show changes before the patient experiences an exacerbation. ${ }^{20}$ Previous studies using PEF values as clinical outcomes for asthma therapy have been conducted by Burkhart et al., ${ }^{21}$ Harrison et al., ${ }^{22}$ and Ramsay et al. ${ }^{23}$

Table 2 showed an increase in PEF values at To to $\mathrm{T}_{4}$, indicating an improved effect after using fish oil in the study sample for four weeks. Table 5 showed a significant change every week, but the increase does not occur the same every week. It was due to several factors that can affect the PEF value, such as differences in activity and weather every week that cannot be controlled. The researcher cannot control the activity because the study sample is a student who has a dense activity. Besides that, the research is also carried out during the rainy season, which can increase the research sample's sensitivity so that it causes the emergence of asthma exacerbations.

It was also strengthened by the results of statistical analysis test results of PEF values between To, T1, T2, T3, T4, and K1, which have $\mathrm{p}=0.000 \quad(\mathrm{p}<0.005)$ then Ho was accepted, meaning that the value of PEF after the use of fish oil was significantly different statistics. Researchers choose four weeks as the minimum time for fish oil intervention because a previous study stated that fish oil's effects appeared after a minimum consumption of 4 weeks. However, there was no further research if fish oil is consumed for more than four weeks. It was expected that further research would be on the effect of improving PEF values after fish oil use for more than four weeks.

Several factors affect the PEF value and can be controlled by researchers, such as food and drugs consumed by research subjects. Control of this factor is done by providing a logbook containing a list of foods and medicines consumed daily by the study sample for four weeks of research. Factors characteristic of the study sample that can affect the PEF value include gender, physical activity, nutrition/food intake, asthma treatment used, occupation, and lung function.

According to Zein and Erzurum, ${ }^{24}$ in women, the influence of estrogen and progesterone hormones cause a high risk of asthma during and after puberty. Asthma is, therefore, more common in women after puberty compared to men. ${ }^{1}$ The same thing was expressed by the Center for Disease Control and Prevention (CDC) in 2016, which said that women's prevalence was higher than men's. ${ }^{25}$ Respondents in this study were teenagers aged 17-25 years at 96.15\%, early adulthood $41-60$ years at $3.85 \%$, and late adulthood at $36-45$ years at $0 \%$.

Exercise-induced asthma is a symptom of asthma that arises in non-asthmatic patients due to excessive physical activity. When someone is doing strenuous physical activity, they will breathe more, faster through the mouth. It then causes the air that enters the lungs to be colder and drier than normal air. A bronchial membrane in the lungs can swell, which then appears asthma symptoms such as wheezing. Exercise-induced asthma generally occurs in winter.26 Entertaining physical activity classified as heavy can trigger an exacerbation in patients with asthma that is not controlled. Some also suffer from exacerbations only during physical activity. ${ }^{1}$

The appearance of asthma symptoms can be related to food chemicals that can cause individual reactions. It is related to a person's level of intolerance. ${ }^{1}$

Outpatient asthma treatment is divided into two, namely the controller and reliever. The controller is a treatment used daily in the long term to keep asthma under clinical control through its anti-inflammatory effects. Whereas reliever is a treatment used when necessary and quickly to reduce bronchoconstriction and reduce the acute symptoms that accompany it. ${ }^{1}$ In this study, all respondents were in step 1, which means that none of the respondents used a type of asthma control controller to maintain asthma control daily. All respondents only used asthma reliever when experiencing worsening symptoms (reliever). This type of reliever's primary choice is short-acting beta-2 agonist (SABA), which is generally salbutamol by the route of inhalation administration. The inhalation route is preferred because it is topical, so side effects tend to be smaller and can work directly to the bronchioles' target site. ${ }^{1}$ However, from the 
respondents' treatment data, some respondents use corticosteroids (oral or inhalation) and methylxanthine group, which is an asthma therapy in the controller group.

In this study, 26 subjects were taken as respondents who have jobs as students (100\%). Wijnhoven et al., ${ }^{27}$ in their study, stated that asthma patients with a higher level of education had a better quality of life than asthma patients with a lower level of education.Therefore, in this study, the work factor involves respondents who have status as students.

Measurement of lung function in this study assesses PEF with peak flow meters of the same type and brand. The condition of patients experiencing asthma exacerbations also affects the ability of research subjects when blowing peak flow meters. The amount of air will influence the device breathed (inspiration) and the amount of air exhaled (expiration). Whereas when patients have asthma exacerbations, the patient experiences impaired limitations in expiration. ${ }^{1}$ Also, other factors can influence PEF measurements, such as body weight and socioeconomic status.

In this study, the best value prediction examination was not carried out because the patient first used the device and could not get the patient's height due to the condition or condition of the patient, which made it impossible to measure height in patients who had asthma exacerbations in the emergency room, so the predictive value in patients using the average height of Indonesians, namely for men at 162.5 $\mathrm{cm}$ and women $151.2 \mathrm{~cm}^{28}$

There are still weaknesses and shortcomings in conducting research, although researchers have tried their best to make the research results perfect. Researchers realize that the study's limitations include: (1) respondents' inclusion criteria such as heart and kidney history data were not obtained accurately. Because when the respondent said that there was no history of heart and kidney, it was not supported by checking the doctor first by using an electrocardiogram (EKG); (2) the type of fish oil used in this study is fish oil from abroad. Researchers used this type of fish oil because the dose was by the desired fish oil dose of 1.o gram. Therefore respondents felt uncomfortable consuming fish oil, which was considered quite large because some respondents commented on the large soft capsule; and (3) there are time variations that can affect PEF values.
The PEF value variability depends on the diurnal cycle (morning and evening values are different), and the expected value of this variability $<20 \%{ }^{1,4}$

\section{Conclusion}

Fish oil containing omega-3 effectively increases lung function every week in asthma patients, from the first week of therapy to the fourth week.

\section{Conflict of Interest}

There were no conflicts of interest related to this research.

\section{Acknowledgments}

We thank participants for their willingness to be involved in the research and the Faculty of Pharmacy at the Universitas Surabaya, who provided support for infrastructure in carrying out this research. Also, we thank the Research and Community Service (LPPM) Universitas Surabaya, which has funded this research.

\section{References}

1. Global Initiative for Asthma. Global strategy for asthma management and prevention. 2019. [cited 2019 September 29]. Available from: http://ginasthma.org/2019-ginareport-global-strategy-for-asthmamanagement-and-prevention/

2. Oemiati R, Sihombing M, Qomariah. Faktorfaktor yang berhubungan dengan penyakit asma di indonesia. Media Litbang Kes. 2010;20(1):41-9.

3. Global Asthma Network. The Global asthma report; 2014. [cited 2019 September 29]. Available from: http://www. globalasthmareport.org/resources/Global_ Asthma_Report_2014.pdf.

4. Shanmugam S, Varughese J, Nair MA,Balasubramanian R, Velu S, Bhojan $\mathrm{C}$, et al. Pharmaceutical care for asthma patients: A Developing Country's Experience. $J$ Res Pharm Pract. 2012;1(2):66-71. doi:10.4103/2279-042X.108373.

5. Lorensia A, Wijaya RI. Hubunganjumlah obat yang digunakan terhadap risiko terjadinya drug-related problems pada pasien asma di suatu rumah sakit di Surabaya. J Trop Pharmacy Chem. 2016;3(3):232-8. 
6. Lorensia A, Queljoe DD, Karina BL, Hewu A. Studi kelengkapan penjelasan cara penggunaan sediaan controller inhaler (kombinasi kortikosteroid dengan beta-2 agonis) jenis Diskus $\AA$ dan Turbuhaler $₫$ oleh apoteker di apotek. JIM. 2016;2(2):137-46.

7. Lorensia A, Ikawati Z, Andayani TM, Maranatha D, Wahjudi M. Analisis kejadian leukositosis pasca terapi aminofilin intravena dibandingkan dengan salbutamol nebulasi pada pasien eksaserbasi asma. IJCP. 2016;5(3):149-59.

8. Lorensia A, Ikawati Z, Andayani TM, Maranatha D, Wahjudi M. Comparison of electrolyte disturbance of using intravenous aminophylline versus nebulization salbutamol for exacerbation asthma in Surabaya, Indonesia. IJPCR. 2016;8(4): 221-8.

9. Lorensia A, Amalia RA. Studi farmakovigilans pengobatan asma pada pasien rawat inap di suatu rumah sakit di Bojonegoro. JIM. 2015;1(1):8-18.

10. Lorensia A, Canggih B, Wijaya RI. Analisa adverse drug reactions pada pasien asma di suatu rumah sakit, Surabaya. JFI. 2013;6(3):142-50.

11. Lorensia A, Wahjuningsih E, Supriadi. Keamanan penggunaan aminofilin pada asma di Rumah Sakit Delta Surya Sidoarjo. IJCP. 2012;1(4):154-61.

12. Lorensia A, Wijaya RI, Canggih B. Studi efektifitas biaya terkait pemilihan obat asma bronkiale rawat inap di suatu rumah sakit swasta di Surabaya. JIST. 2013;7(1):56-63.

13. Rosenkranz RR. Rosenkranz SK. Neessen KJ. Dietary factors associated with lifetime asthma or hayfever diagnosis in Australian middle-aged and older adults: a crosssectional study. Nutr J. 2012;11:84.

14. Thien FCK, Luca SD, Woods RK, Abramson MJ. Dietary marine fatty acids (fish oil) for asthma in adults and children (Review). Cochrane Database Syst Rev. 2002;2: CDoo1283.

15. Fotenko O, Zeki A, Schuster G, Davis C, Allayee H, Stephensen C, et al. Asthma patients with specific genotypes identified for fish oil treatment trial. California Agriculture. 2011;65(3):112-7.

16. Aprizayanti. Hubungan konsumsi omega 3 terhadap tumbuh kembang anak usia 2-3 tahun di wilayah kerja Puskesmas Sebarang
Padang Kota Padang Tahun 2011.Padang; 2011.

17. Santoso A, Iriyanti N, S Tri Rahardjo. Penggunaan pakan fungsional mengandung omega 3, probiotik dan isolat antihistamin n3 terhadap kadar lemak dan kolesterol kuning ayam kampung. Jurnal Ilmiah Peternakan; 2013;1(3):848-55.

18. Asthma Management Handbook. National Asthma Council Australia; 2006. [cited 2019 September 29]. Available from: https:// www.nationalasthma.org.au/healthprofessionals/australian-asthma-handbook

19. Calder PC. Immunomodulation by omega-3 fatty acids. Prostaglandins Leukot Essent Fatty Acids. 2007;77:327-35.

20. American Lung Association. Measuring your peak rate; 2015. [cited 2019 September 29]. Available from: http://www.lung.org/lunghealth-and-diseases/lung-disease-lookup/ asthma/living-with-asthma/managingasthma/measuring-your-peak-flow-rate. html

21. Burkhart PV, Rayens MK, Oakley MG. Effect of peak flow monitoring on child asthma quality of life. J Pediatr Nurs. 2012;27(1):1825. doi:10.1016/j.pedn.2010.11.001.

22. Harrison TW, Oborne J, Newton S, Tattersfield AE. Doubling the dose of inhaled corticosteroid to prevent asthma exacerbations: randomised controlled trial. Lancet. 2004;363(9405):271-5.

23. Ramsay CF. Pearson D, Mildenhall S, Wilson AM. Oral montelukast in acute asthma exacerbations: a randomised, doubleblind, placebo-controlled trial. Thorax. 2011;66(1):7-11.

24. Zein JG, Erzurum SC. Asthma is Different in Women. Curr Allergy Asthma Rep. 2015;15(6):28. doi:10.1007/s11882-0150528-y.

25. Center for Disease Control and Prevention (CDC). Data, statistics, and surveillance; 2016. [cited 2019 September 29]. Available from: https://www.cdc.gov/asthma/ asthmadata.htm

26. Weiler JM, Brannan JD, Randolph CC, Hallstrand TS, Parsons J, Silvers W, et al. 2016. Exercise-induced bronchoconstriction update-2016. J Allergy Clin Immuol. 138(5):1292-5.e36.

27. Wijnhoven HA, Kriegsman DM, Hesselink AE, Penninx BW, de Haan M. Determinants 
of different dimensions of disease severity in asthma and COPD: pulmonary function and health-related quality of life. Chest. 2001;119(4):1034-42.

28. Langtree I. Height chart of men and women in different countries. disabled world; 2017. [cited 2019 September 29]. Available from: https://www.disabled-world.com/ calculators-charts/height-chart.php. 


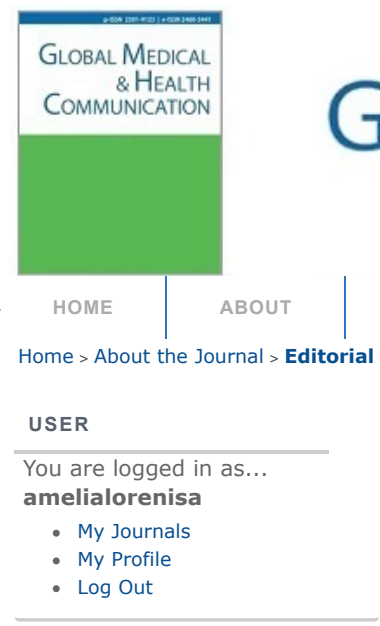

GMHC Indexed by:
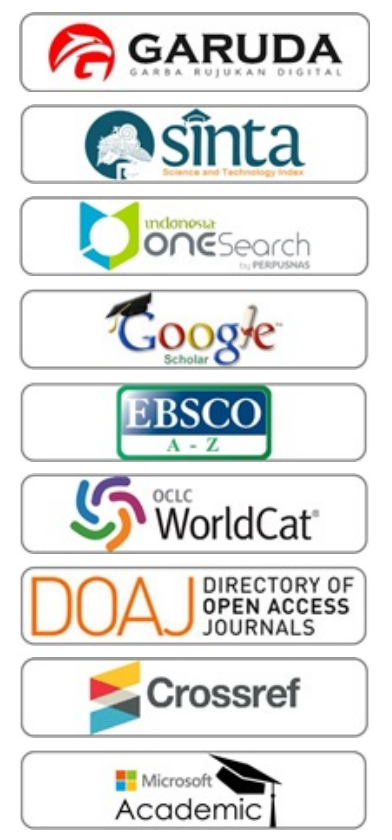

GMHC Template

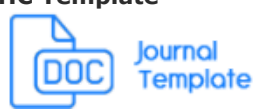

Ethic \& Plagiarism Template

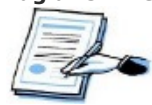

Copyright Transfer Statement

(C)opyright
Global Medical \& Health Communication

pISSN 2301-9123 | elSSN 2460-5441

USER HOME

SEARCH

CURRENT

ARCHIVES

SUBMISSIONS

REVIEWER

EDITORIAL TEAM

Editor in Chief

Herry Garna, Department of Child Health, Faculty of Medicine, Universitas Islam Bandung, Bandung, Indonesia

Editorial Board

Arief Budi Yulianti, Department of Medical Biology and Histology, Faculty of Medicine, Universitas Islam Bandung, Bandung, Indonesia

Badrul Hisham Yahaya, Advanced Medical and Dental Institute, Universiti Sains Malaysia, Kepala Batas, Malaysia Caecielia Makaginsar, Department of Physiology, Faculty of Medicine, Universitas Islam Bandung, Bandung,

Indonesia

Ike Rahmawaty Alie, Department of Physiology, Faculty of Medicine, Universitas Islam Bandung, Bandung, Indonesia

Jerico Franciscus Pardosi, School of Public Health and Social Work, Queensland University of Technology, Kelvin Grove, Queensland, Australia

Lisa Adhia Garina, Department of Child Health, Faculty of Medicine, Universitas Islam Bandung, Bandung, Indonesia

Listya Hanum Siswanti, Department of Histology, Faculty of Medicine, Universitas Islam Bandung, Bandung, Indonesia

Mirasari Putri, Department of Biochemistry, Faculty of Medicine, Universitas Islam Bandung, Bandung, Indonesia Roy Rillera Marzo, Asia Metropolitan University, Johor, Malaysia

Winni Maharani, Department of Microbiology, Faculty of Medicine, Universitas Islam Bandung, Bandung,

Indonesia

Yuktiana Kharisma, Departement of Pharmacology, Faculty of Medicine, Universitas Islam Bandung, Bandung, Indonesia

\section{Proofreader}

Herry Garna, Department of Child Health, Faculty of Medicine, Universitas Islam Bandung, Bandung, Indonesia Copyeditor

Yudi Feriandi, Department of Public Health, Faculty of Medicine, Universitas Islam Bandung, Bandung, Indonesia Layout Editor

Agus Chalid, GMHC, JIKS, Faculty of Medicine, Universitas Islam Bandung, Bandung, Indonesia

Editorial Assistants

Deni Irawan, JIKS, GMHC, Fakultas Kedokteran, Indonesia

Evi Apriani, Universitas Islam Bandung, Bandung, Indonesia

Yani Cahyani, Universitas Islam Bandung, Bandung, Indonesia

Zaenal Arifin, Faculty of Medicine, Universitas Islam Bandung, Bandung, Indonesia

\section{AUTHOR GUIDEUNES}

ONLINE SUBMISSION

FOCUS AND SCOPE

EDITORIAL TEAM

PEER REVIEWERS

PUBLICATION ETHICS

ABSTRACT AND INDEXING

\section{AUTHOR FEES}

CITATIONS

ACCREDITATION

Sinta Ranking: 2

Number: 30/E/KPT/2019

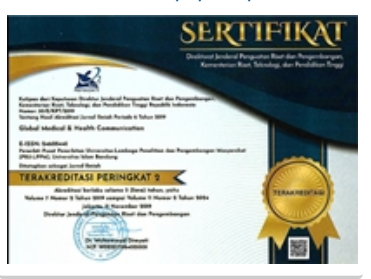

RECOMMENDED TOOLS

EndNote

\%. MENDELEY

turnitin (2)

G grammarly

Free counters!

c) (i) (2)

This work is licensed under a Creative Commons Attribution-NonCommercial-ShareAlike 4.0 International License.

\section{NOTIFICATIONS \\ - View (9 new) \\ - Manage}




\section{Global Medical \& Health Communication}

USER HOME

\author{
SEARCH
}

CURRENT

ARCHIVES

SUBMISSIONS

REVIEWER

\section{GLOBAL MEDICAL \& HEALTH \\ COMMUNICATION

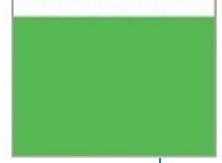 \\ HOME $\quad$ ABOUT \\ Home > Vol 8, No 3 (2020) \\ USER \\ You are logged in as... \\ amelialorenisa \\ - My Journals \\ - My Profile \\ - Log Out}

\section{GMHC Indexed by:}

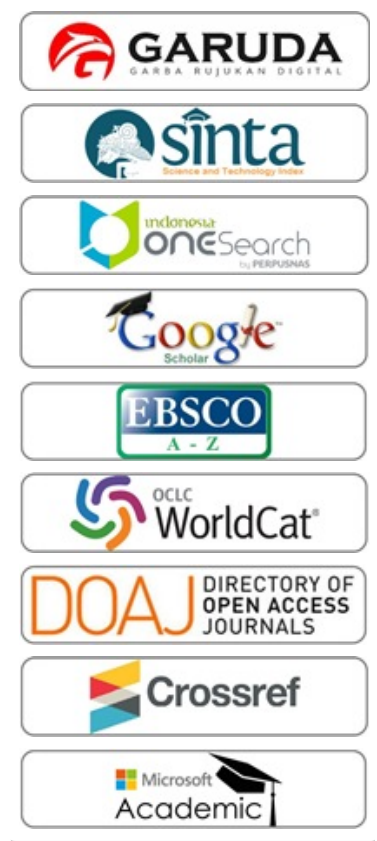

GMHC Template

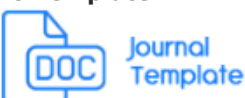

Ethic \& Plagiarism Template

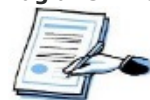

Copyright Transfer Statement

\section{(C) opyright}

\section{GLOBAL MEDICAL \& HEALTH COMMUNICATION}

The Global Medical \& Health Communication (GMHC) is a journal that publishes medical and health articles since 2013. Articles are original research that needs to be disseminated and written in English.

In not so long time, GMHC journal published by Faculty of Medicine, Universitas Islam Bandung have already accredited by Ministry of Research, Technology and Higher Education of the Republic of Indonesia Number 30/E/KPT/2019 valid for 5 (five) years from Volume 7 Number 2 with Sinta (Science and Technology Index) Score is S2. It's also indexed in Directory of Open Access Journals (DOAJ) on 9th May 2017 and Crossref on 2nd January 2018, with DOAJ and Crossref indexing this journal are able to reach international audiences. This achievement received positive responses from researchers, lecturers and health observers alike showed by articles submitted which are triple compare to the number of articles received in its early time. The quality of the articles also show improvement both in methodology and written that will be beneficial for audiences. Research findings were best to disseminate as early as possible so they can be used properly. To support these GMHC publication which was every $\mathbf{6}$ (six) months in a year will publish every 4 (four) months in one year starting from 2017. The news from science and health about challenges and opportunities in Indonesia is still very quiet that GMHC hopes to become the best means to support researchers, lecturers, and health practitioners to become the voice of Indonesia, especially in health. pISSN 2301-9123 | eISSN 2460-5441.

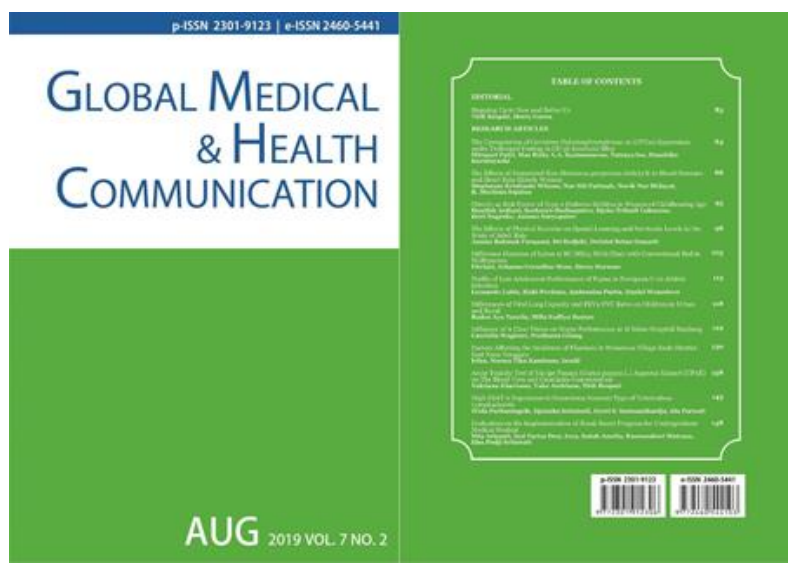

VOL 8 , NO 3 (2020)

DECEMBER 2020

TABLE OF CONTENTS

Articles

The Differences in Maternal Compliance in Completing Basic Immunization between Two PDF Groups

Ita Susanti, Dewi Marhaeni Diah Herawati, Eddy Fadlyana, Herry Herman, Kusnandi Rusmil, Firman Fuad Wirakusumah

Lavender Flower/Mandarin Orange Peel Essential Oil-Soybean Oil to Repel Culex sp.

Susy Tjahjani, Hanan Aulalia, Genevieve Annishaningrat Zailani

The Risk Factors of Motorcycle Riders Traffic Accidents in Semarang City 2017 Mochammad Malik Ibrahim, Mateus Sakundarno Adi, Suhartono Suhartono

Soil-Transmitted Helminths Contamination on the Yard's Soil of the Public Elementary Schools in Bandung City

Ratna Dewi Indi Astuti, Ismawati Ismawati, Hilmi Sulaiman Rathom

Midwives Knowledge, Infrastructure Facilities, and Supervision-Monitoring of Immunization Management in West Bandung Regency

Fathia Rizki, Adjat Sedjati Rasyad, Herry Garna

Cogongrass (Imperata cylindrica L.) Ethanol Extract on Sepsis Mice Model Body Weight and Sepsis Score

Mirasari Putri, Neni Anggraeni, Raden Aliya Tresna M. D., Ghaliby Ardhia Ramli, Mia

Kusmiati, Yuke Andriane, Eka Hendryanny, Abdul Hadi Hassan, Meta Maulida

Damayanti, Nugraha Sutadipura, Mas Rizky A. A. Syamsunarno

Pilot Study of Lung Function Improvement in Peak Expiratory Flow (PEF) Value Using Fish Oil Containing Omega-3 Therapy in Asthma

Amelia Lorensia, Rivan Virlando Suryadinata, Richa Ratnasari

Dengue Cases Prediction in Kupang

Titik Respati, Wanti Wanti, Ricvan Dana Nindrea

$192-198$

Knowledge

Windi Nurdiawan, Chrestella Odillia, Monica Risnadena Priyas, Yosefa Resti Radinda,

Nabila Alifia Ahmad, Nur Agustina Ningsih, Qhonita Anif Febian, Andri Rezano

The Development of Germicidal Air Purifier by Employing Ultraviolet System in Controlling
PDF

PDF

181-185

PDF 186-191

PDF

PDF

199-205

AUTHOR GUIDEUNES

ONLINE SUBMISSION

FOCUS AND SCOPE

EDITORIAL TEAM

PEER REVIEWERS

PUBLICATION ETHICS

ABSTRACT AND INDEXING

AUTHOR FEES

CITATIONS

ACCREDITATION

Sinta Ranking: 2

Number: 30/E/KPT/2019

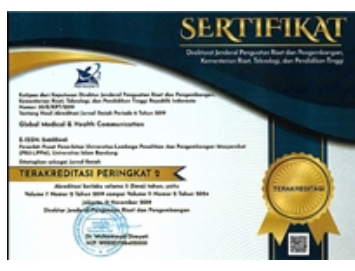

RECOMMENDED TOOLS

EndNote

s. Mendeley

turnitin (2)

G grammarly

\section{NOTIFICATIONS}

- View (9 new)

- Manage

CURRENT ISSUE

206-210

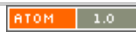

\begin{tabular}{|l|l|l|}
\hline RSS & 2.0 \\
\hline
\end{tabular}

\begin{tabular}{|l|l|}
\hline RSS & 1.0 \\
\hline
\end{tabular}

OPEN JOURNAL SYSTEMS

Journal Help 
Nur Atik, Siska Widya Dewi Kusumah, Fitria Mahrunnisa, Winni Maharani, Windi

Nurdiawan, Putu Indra Cyntia Dewi, Erda Avriyanti, Dede Suhendi

The Influence of Gestational Age and Birth Weight on Neonatal Mortality Wedi Iskandar, Yeni Andayani, Lia Marlia, Burhan Burhan, Aris Primadi

PDF 239-244

Cogongrass (Imperata cylindrical L.) Roots Ethanol Extract to Improve Hematological Profile in Carbon Tetrachloride-Injection Mice Model

PDF $245-250$

Anisah Dahlan, Fitria Hariati Ramdhani, Neni Anggraeni, Irma Melyani Puspitasari,

Mirasari Putri, Mas Rizky A. A. Syamsunarno

pISSN 2301-9123 | eISSN 2460-5441

Visitor since 19 October 2016:

View My Stats

Free counters!

(1) (1)(0)

This work is licensed under a Creative Commons Attribution-NonCommercial-ShareAlike 4.0 International License. 